\title{
CONTROL OF RESTING HEART RATE AND OTHER RISK FACTORS OVER A THREE-YEAR PERIOD IN OUTPATIENTS WITH STABLE CORONARY ARTERY DISEASE IN LATVIA
}

\author{
Inga Balode*, Sanda Jēgere ${ }^{\star *}$, Iveta Bajāre***, Iveta Mintāle**, Inga Narbute**,

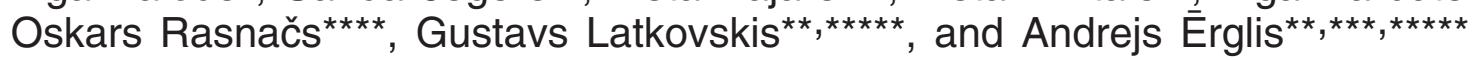 \\ * Rīga Stradiṇš University, Dzirciema 16, Rīga, LV-1017, LATVIA; \\ inga.balode@inbox.lv \\ ** Latvian Centre of Cardiology, Pauls Stradiṇš Clinical University Hospital, Pilsoṇu iela 13, Rīga, LV1002, LATVIA \\ ${ }^{* * *}$ Research Institute of Cardiology, University of Latvia, Pilsoṇu iela 13, Rĩga, LV1002, LATVIA \\ *** Faculty of Medicine, Rīga Stradinš University, Dzirciema iela 16, Rīga, LV-1017, LATVIA \\ ${ }^{* \star * \star *}$ Faculty of Medicine, University of Latvia, Raina bulv. 19, Rĩga, LV-1586, LATVIA
}

Contributed by Andrejs Ërglis

\begin{abstract}
The aim of the study was to evaluate control of heart rate (HR) and other risk factors (RF) over a three-year period in coronary artery disease $(C A D)$ outpatients in Latvia. Patients $(n=120)$ were examined and questioned at baseline time and annually (four times in total). Increased resting $H R$ $(\geq 70 \mathrm{bpm})$ when measured by palpation was present in $35.8 \%$ of cases at baseline time, $35.6 \%$, $29.8 \%$ and $35.1 \%$ of cases at $Y 1, Y 2$ and $Y 3$, respectively; when measured by electrocardiography: in $33.6 \%$ (baseline), 36.8\% (Y1), 26.7\% (Y2), 33.7\% (Y3) of cases. The proportion of patients with increased HR did not significantly change in $Y 1-Y 3$ vs baseline. Systolic blood pressure was lower in $Y 1$ and $Y 3$ vs baseline $(\mathrm{P}=0.005$ and $\mathrm{P}=0.003$, respectively). The proportion of patients with increased blood pressure $(\geq 140 / 90 \mathrm{mmHg})$ was lower in $Y 1$, Y2 and Y3 than at baseline $(\mathrm{P}=0.018, \mathrm{P}=0.030$ and $\mathrm{P}=0.017$, respectively). The proportion of patients with a decreased level of high density lipoprotein cholesterol $(<1.2 \mathrm{mmol} / \mathrm{l}$ for women and $<1.0$ $\mathrm{mmol} / \mathrm{l}$ fom men) was lower in Y1-Y3 compared to baseline ( $\mathrm{P}<0.001)$. A substantial (about one-third) and stable proportion of patients with increased $H R \geq 70 \mathrm{bpm}$ over the three-year period in the examined sample of treated CAD patients indicates that there is a need for better control of this RF.
\end{abstract}

Key words: increased resting heart rate, cardiovascular risk, coronary artery disease, heart rate reducing agents.

\section{INTRODUCTION}

Coronary artery disease (CAD) is a highly prevalent cardiovascular $(\mathrm{CV})$ pathology and is the main cause of mortality worldwide and a major burden on public health (Leal et al., 2006). It will remain the leading cause of death for coming years (Mathers and Loncar, 2006). CV mortality in Latvia is higher than in the European Union on average (Anonims, 2011). Due to aging of the population and improved prognosis of coronary patients, the number of CAD patients in the future may increase (Tunstall-Pedoe et al., 1999). Despite recent advances in management of CAD via more effective treatment for acute coronary syndrome, revascularisation and improved prevention, CAD remains a major public health concern and improvement in outcome of the disease continues to be a challenge.

Understanding of the cardiovascular (CV) risk factors (RFs) and treatment have markedly changed over the years. Dur- ing the last decade, strong evidence has supported the concept about resting heart rate (HR) as an important prognostic RF (Diaz et al., 2005; Fox et al., 2008a; Bohm et al., 2010). Both the BEAUTIFUL and SHIFT studies in a prospective way confirmed the prognostic value of increased resting HR. BEAUTIFUL showed an association of HR $\geq 70$ beats per minute (bpm) with significantly increased $\mathrm{CV}$ risk in CAD patients with left ventricular dysfunction (Fox et al., 2008a). Another prospective study, SHIFT, confirmed high $\mathrm{HR}$ as a RF and important target for treatment in heart failure (Bohm et al., 2010).

Based on a large body of evidence, high resting HR as an independent CV RF is included in the European and Latvian guidelines on CV disease prevention (Ërglis u.c., 2007; Graham et al., 2007; Perk et al., 2012).

Taking into account the evolving concept of high resting $\mathrm{HR}$ as an important correctable RF in CAD, there is increas- 
ing demand for data regarding the level of HR control in clinical practice, particularly in outpatients.

The aim of the study was to evaluate control of resting HF as well as other RFs over three-year period in treated outpatients with established stable CAD, by annual collection and analysis of information about RFs (including increased HR), medical history, physical examination and clinical data, as well as the treatment. Following our previous publication on baseline data of the study (Balode et al., 2011), the current paper focuses on three-year follow-up data.

\section{MATERIALS AND METHODS}

We surveyed 120 treated outpatients with established stable CAD. Ten cardiologists and two general practitioners working in different regions of Latvia took part in the study, by including 6 to $12 \mathrm{CAD}$ patients each and observing them over a three-year period (from November 2009 to April 2013). CAD was confirmed by history of at least one inclusion criteria: documented myocardial infarction (more than three months ago), coronary stenosis more than $50 \%$ (confirmed by coronary angiography), chest pain in combination with myocardial ischemia (confirmed by stress ECG, stress echocardiography or myocardial imaging), coronary revascularisation (coronary artery bypass graft (CABG) or percutaneous coronary intervention (PCI)) more than three months ago. Exclusion criteria were hospitalisation due to $\mathrm{CV}$ disease within the last three months, planned revascularisation and limited cooperation of a patient. A case report form for baseline data contained the following parts: demographic information, RFs and lifestyle, medical history, physical examination, current symptoms, most recent measurements (glucose level, total cholesterol, high density lipoprotein cholesterol (HDL-C), low density lipoprotein cholesterol (LDL-C), triglycerides, left ventricular ejection fraction (LVEF)), and current treatment. After the inclusion visit when baseline data were collected, patients were questioned and examined once per year during annual visits. During the whole follow-up period, four measurements per each parameter were collected (if available) for each patient. A case report form for annual data contained the following parts: clinical outcomes, RFs and lifestyle, physical examination, current symptoms, most recent measurements and treatment. The resting HR was estimated by two methods: pulse palpation and electrocardiography (ECG). Pulse palpation was performed after sitting for at least $5 \mathrm{~min}$ in a quiet room with comfortable temperature; then HR was measured for 30 seconds, two measurements were taken, and the second was recorded. For ECG the most recent ECG within six months was used. No special investigations, measurements or treatment changes took place during this observational study. Over the entire follow-up period, patients were managed in a normal manner by treating physicians.

High HR was defined as $\geq 70$ (bpm) according to recent evidence (Fox et al., 2008a). In accordance with Latvian guidelines on CV prevention (Ērglis u.c., 2007): total cho- lesterol $\geq 5 \mathrm{mmol} / 1, \mathrm{LDL}-\mathrm{C} \geq 3 \mathrm{mmol} / \mathrm{l}$, triglycerides $\geq 1.7$ $\mathrm{mmol} / \mathrm{l}$, glucose level $\geq 5.6 \mathrm{mmol} / \mathrm{l}$, body mass index (BMI) $\geq 25 \mathrm{~kg} / \mathrm{m}^{2}$, systolic blood pressure $\geq 140 \mathrm{mmHg}$ and diastolic $\geq 90 \mathrm{mmHg}$ were assessed as high; HDL-C level was defined as low at $<1.2 \mathrm{mmol} / \mathrm{l}$ for women and $<1 \mathrm{mmol} / \mathrm{l}$ fom men. BMI was calculated by using height and weight in $\mathrm{kg} / \mathrm{m}^{2}$. Waist circumference $\geq 80 \mathrm{~cm}$ for women and $\geq 94$ $\mathrm{cm}$ for men was defined as increased according to criteria of metabolic syndrome (Alberti et al., 2005).

Target doses for $\beta$ blockers were defined as follows: 200 $\mathrm{mg}$ daily (mg/d) for metoprolol, $10 \mathrm{mg} / \mathrm{d}$ for bisoprolol and nebivolol and $50 \mathrm{mg} / \mathrm{d}$ for carvedilol in accordance with the expert consensus document on $\beta$-adrenergic receptor blockers (Lopez-Sendon et al., 2004) and the newest European heart failure guidelines (McMurray et al., 2012). The target dose for betaxolol was defined as $20 \mathrm{mg} / \mathrm{d}$ according to SPC (Summary of Product Characteristics) (Anonīms, 2013a).

Approval of the Ethics Committee of the Research Institute of Cardiology, University of Latvia, was obtained before enrollment of patients into study.

$P$ values $<0.05$ were considered as statistically significant.

Data were processed with methods of descriptive as well as analytical statistics using the Statistical Package for the Social Sciences (SPSS), version 20.0.

\section{RESULTS}

Heart rate. HR values at baseline and during the follow-up period are summarised in Table 1. When compared, only HR values measured by palpation differed (were lower) from baseline data in Y2 (Wilcoxon test, $P=0.027$ ). The proportion of patients with increased HR at baseline as well as during the follow-up period was about one-third (Table 2). When comparing Y1, Y2, Y3 values with baseline data, no significant changes in the proportion of patients with increased HR were found (McNemar's test, $P>0.05$ ).

Clinical outcomes. During the three-year period, of 120 patients participating in the study, at least one clinical outcome was documented in $45(37.5 \%)$ patients: 5 (4.2\%) patients died and $40(33.3 \%)$ had non-fatal clinical outcome. In the majority of cases $(n=4)$, death was due to $\mathrm{CV}$ reasons, one patient died from non-CV disease. In total, 88 non-fatal CV events were documented during follow-up. The most frequent were coronary angiography, unstable angina and percutaneous coronary intervention (PCI) (Table 3).

Mean baseline HR in patients with or without any clinical outcome was $66.1 \pm 9.7 \mathrm{bpm}$ (by pulse palpation), $65.5 \pm$ 10.9 bpm (by ECG), $68.2 \pm 8.9$ bpm (by pulse palpation), and $67.4 \pm 10.2 \mathrm{bpm}$ (by ECG), respectively. No statistically significant differences were found between patients with or without clinical events in terms of baseline HR (independent t-test, $P>0.050$ for both comparisons). Mean 
HEART RATE AT BASELINE AND DURING THREE-YEAR FOLLOW-UP

\begin{tabular}{|c|c|c|c|}
\hline Period & $\begin{array}{c}\text { HR measurement } \\
\text { method }\end{array}$ & $\begin{array}{c}\text { Statistical } \\
\text { values }\end{array}$ & HR (bpm); n \\
\hline \multirow[t]{8}{*}{ Baseline } & Palpation & M & 67.7 \\
\hline & & $\mathrm{Me}$ & 65.5 \\
\hline & & IQR & 9.5 \\
\hline & & $\mathrm{n}$ & 120 \\
\hline & ECG & M & 66.9 \\
\hline & & $\mathrm{Me}$ & 65.0 \\
\hline & & IQR & 14.0 \\
\hline & & $\mathrm{n}$ & 119 \\
\hline \multirow[t]{8}{*}{ Y1 } & Palpation & M & 67.9 \\
\hline & & $\mathrm{Me}$ & 66.0 \\
\hline & & IQR & 8.0 \\
\hline & & $\mathrm{n}$ & 118 \\
\hline & ECG & M & 66.9 \\
\hline & & $\mathrm{Me}$ & 65.0 \\
\hline & & IQR & 15.3 \\
\hline & & $\mathrm{n}$ & 114 \\
\hline \multirow[t]{8}{*}{ Y2 } & Palpation & M & 66.0 \\
\hline & & SD & \pm 8.3 \\
\hline & & $\mathrm{Me}$ & 64.0 \\
\hline & & $\mathrm{n}$ & 114 \\
\hline & ECG & M & 67.7 \\
\hline & & $\mathrm{Me}$ & 63.0 \\
\hline & & IQR & 12.0 \\
\hline & & $\mathrm{n}$ & 101 \\
\hline \multirow[t]{8}{*}{ Y3 } & Palpation & M & 68.5 \\
\hline & & $\mathrm{Me}$ & 65.5 \\
\hline & & IQR & 12.3 \\
\hline & & $\mathrm{n}$ & 114 \\
\hline & ECG & M & 65.9 \\
\hline & & $\mathrm{Me}$ & 67.0 \\
\hline & & IQR & 14.5 \\
\hline & & $\mathrm{n}$ & 101 \\
\hline
\end{tabular}

bpm, beats per minute; ECG, electrocardiography; HR, heart rate; IQR, interquartile range; $\mathrm{M}$, mean; Me, median; $\mathrm{n}$, number of patients with measured HR; SD, standard deviation; Y, year

Table 2

DISTRIBUTION OF PATIENTS OVER A THREE-YEAR PERIOD ACCORDING TO HEART RATE LEVEL

\begin{tabular}{|c|c|c|c|c|c|c|c|c|c|}
\hline \multirow{3}{*}{$\begin{array}{l}\text { HR measure- } \\
\text { ment } \\
\text { method }\end{array}$} & \multirow[t]{3}{*}{ HR levels } & \multicolumn{8}{|c|}{ Period } \\
\hline & & \multicolumn{2}{|c|}{ baseline } & \multicolumn{2}{|c|}{ Y1 } & \multicolumn{2}{|c|}{$\mathrm{Y} 2$} & \multicolumn{2}{|c|}{$\mathrm{Y} 3$} \\
\hline & & $\mathrm{n}$ & $\%$ & $\mathrm{n}$ & $\%$ & $\mathrm{n}$ & $\%$ & $\mathrm{n}$ & $\%$ \\
\hline \multirow[t]{3}{*}{ Palpation } & HRF bpm & 77 & 64.2 & 76 & 64.4 & 80 & 70.2 & 74 & 64.9 \\
\hline & $\mathrm{HR} \geq 70 \mathrm{bpm}$ & 43 & 35.8 & 42 & 35.6 & 34 & 29.8 & 40 & 35.1 \\
\hline & Total & 120 & 100 & 118 & 100 & 114 & 100 & 114 & 100 \\
\hline \multirow[t]{3}{*}{ ECG } & HRF bpm & 79 & 66.4 & 72 & 63.2 & 74 & 73.3 & 67 & 66.3 \\
\hline & $\mathrm{HR} \geq 70 \mathrm{bpm}$ & 40 & 33.6 & 42 & 36.8 & 27 & 26.7 & 34 & 33.7 \\
\hline & Total & 119 & 100.0 & 114 & 100.0 & 101 & 100.0 & 101 & 100.0 \\
\hline
\end{tabular}

For abbreviations see Table 1
NON-FATAL CLINICAL OUTCOMES DURING FOLLOW-UP

\begin{tabular}{|c|c|c|c|c|c|}
\hline Year & & linical outcomes & $\begin{array}{l}\text { Number } \\
\text { of events }\end{array}$ & $\begin{array}{c}\% \text { from in- } \\
\text { cluded } 120 \\
\text { patients }\end{array}$ & \begin{tabular}{|c}
$\%$ from pa- \\
tients with an- \\
nual visit
\end{tabular} \\
\hline \multirow[t]{9}{*}{ Y1 } & \multicolumn{2}{|c|}{ Unstable angina } & 4 & $3.3 \%$ & $3.4 \%$ \\
\hline & \multicolumn{2}{|c|}{$\begin{array}{l}\text { Non fatal myocardial infarc- } \\
\text { tion }\end{array}$} & 1 & $0.8 \%$ & $0.8 \%$ \\
\hline & \multicolumn{2}{|c|}{ Coronary angiography } & 10 & $8.3 \%$ & $8.5 \%$ \\
\hline & \multicolumn{2}{|c|}{ PCI } & 3 & $2.5 \%$ & $2.5 \%$ \\
\hline & \multicolumn{2}{|c|}{ Ischemic stroke } & 1 & $0.8 \%$ & $0.8 \%$ \\
\hline & \multicolumn{2}{|c|}{ Atrial fibrillation/flutter } & 3 & $2.5 \%$ & $2.5 \%$ \\
\hline & \multicolumn{2}{|c|}{ Carotid surgery/stenting } & 1 & $0.8 \%$ & $0.8 \%$ \\
\hline & \multirow{2}{*}{$\begin{array}{l}\text { Total } \\
\text { in Y1 }\end{array}$} & Number of events & \multicolumn{3}{|c|}{22} \\
\hline & & $\begin{array}{l}\text { Number of patients } \\
\text { with events }\end{array}$ & 15 & $12.5 \%$ & $12.7 \%$ \\
\hline \multirow[t]{13}{*}{$\mathrm{Y} 2$} & \multicolumn{2}{|c|}{ Unstable angina } & 10 & $8.3 \%$ & $8.7 \%$ \\
\hline & \multicolumn{2}{|c|}{$\begin{array}{l}\text { Non fatal myocardial infarc- } \\
\text { tion }\end{array}$} & 2 & $1.7 \%$ & $1.7 \%$ \\
\hline & \multicolumn{2}{|c|}{ Coronary angiography } & 16 & $13.3 \%$ & $13.9 \%$ \\
\hline & \multicolumn{2}{|c|}{ PCI } & 8 & $6.7 \%$ & $7.0 \%$ \\
\hline & \multicolumn{2}{|c|}{ Unknown stroke } & 1 & $0.8 \%$ & $0.9 \%$ \\
\hline & \multicolumn{2}{|c|}{ Transient ischemic attack } & 1 & $0.8 \%$ & $0.9 \%$ \\
\hline & \multicolumn{2}{|c|}{$\begin{array}{l}\text { Hospitalisation for chronic } \\
\text { heart failure }\end{array}$} & 1 & $0.8 \%$ & $0.9 \%$ \\
\hline & \multicolumn{2}{|c|}{ Implantation of pacemaker } & 1 & $0.8 \%$ & $0.9 \%$ \\
\hline & \multicolumn{2}{|c|}{$\begin{array}{l}\text { Implantation of cardiac } \\
\text { defibrillator }\end{array}$} & 1 & $0.8 \%$ & $0.9 \%$ \\
\hline & \multicolumn{2}{|c|}{ Atrial fibrillation/flutter } & 2 & $1.7 \%$ & $1.7 \%$ \\
\hline & \multicolumn{2}{|c|}{$\begin{array}{l}\text { Abdominal aorta surgery/ } \\
\text { stenting }\end{array}$} & 2 & $1.7 \%$ & $1.7 \%$ \\
\hline & \multirow{2}{*}{$\begin{array}{l}\text { Total } \\
\text { in Y2 }\end{array}$} & Number of events & \multicolumn{3}{|c|}{45} \\
\hline & & $\begin{array}{l}\text { Number of patients } \\
\text { with events }\end{array}$ & 24 & $20.0 \%$ & $20.9 \%$ \\
\hline \multirow[t]{10}{*}{ Y3 } & \multicolumn{2}{|c|}{ Unstable angina } & 3 & $2.5 \%$ & $2.6 \%$ \\
\hline & \multicolumn{2}{|c|}{$\begin{array}{l}\text { Non fatal myocardial infarc- } \\
\text { tion }\end{array}$} & 1 & $0.8 \%$ & $0.9 \%$ \\
\hline & \multicolumn{2}{|c|}{ Coronary angiography } & 6 & $5.0 \%$ & $5.3 \%$ \\
\hline & \multicolumn{2}{|c|}{ PCI } & 3 & $2.5 \%$ & $2.6 \%$ \\
\hline & $\begin{array}{l}\text { Hospit } \\
\text { heart } \mathrm{f}\end{array}$ & $\begin{array}{l}\text { alisation for chronic } \\
\text { ailure }\end{array}$ & 1 & $0.8 \%$ & $0.9 \%$ \\
\hline & Implar & tation of pacemaker & 2 & $1.7 \%$ & $1.8 \%$ \\
\hline & Atrial & fibrillation/flutter & 4 & $3.3 \%$ & $3.5 \%$ \\
\hline & $\begin{array}{l}\text { Periph } \\
\text { gery }\end{array}$ & ery artery disease sur- & 1 & $0.8 \%$ & $0.9 \%$ \\
\hline & Total & Number of events & & 21 & \\
\hline & in $\mathrm{Y} 3$ & $\begin{array}{l}\text { Number of patients } \\
\text { with events }\end{array}$ & 16 & $13.3 \%$ & $14.0 \%$ \\
\hline Y1-Y3 & Numb & er of events & & 88 & \\
\hline & $\begin{array}{l}\text { Numb } \\
\text { events }\end{array}$ & r of patients with & 40 & $33.3 \%$ & \\
\hline
\end{tabular}

PCI, percutaneous coronary intervention; Y, year

baseline HR by pulse palpation and ECG in patients who died during the follow-up period were $72.6 \pm 16.9 \mathrm{bpm}$ and $71.4 \pm 17.4 \mathrm{bpm}$, respectively. However, it did not differ significantly from patients who survived $(67.5 \pm 9.2 \mathrm{bpm}$ by pulse palpation and $66.7 \pm 10.4 \mathrm{bpm}$ by ECG) (independent 
t-test, $P>0.05)$. Mean baseline HR in patients with nonfatal events did not differ significantly from baseline HR in patients without any event; similarly HR in patients with coronary events did not differ from baseline HR in others (independent t-test, $P>0.05$ ).

Other risk factors and lifestyle. Most patients were non-smokers. At Y1 and Y2 there were 19 (15.8\%) smokers, while $18(15.9 \%)$ patients smoked at Y3, compared with $22(18.3 \%)$ at baseline (Wilcoxon test, $P>0.05)$. The mean number of cigarettes per day decreased significantly at $\mathrm{Y} 1$ vs at the baseline visit $(7.8 \pm 4.3$ vs $8.3 \pm 3.9$, respectively) (paired sample t-test, $P=0.015$ ). Mean weight and BMI did not change during the three-year period (Wilcoxon test, $P>0.05)$. The proportion of patients with increased BMI as well as the proportion of patients with increased waist circumference did not change significantly (McNemar's test, $P>0.05$ ). Mean waist circumference increased in women in Y1 vs baseline $(96.5 \pm 13.1$ vs $94.6 \pm$ 12.6, paired sample test, $P=0.048$ ). No other changes in waist circumference were found. Systolic blood pressure was significantly lower at Y1 and Y3 vs baseline data (at baseline: $138.3 \pm 17.1 \mathrm{mmHg}, \mathrm{Me}=140.0 \mathrm{mmHg}$; in $\mathrm{Y} 1$ : $\mathrm{Me}=130.0 \mathrm{mmHg}$, IQR (interquartile range) $=30.0$ $\mathrm{mmHg}$; at $\mathrm{Y} 3: \mathrm{Me}=130.0 \mathrm{mmHg}, \mathrm{IQR}=17.7 \mathrm{mmHg}$ ) (Wilcoxon test, $P=0.005$ (Y1 vs baseline), $P=0.003$ (Y3 vs baseline)). The number of patients with increased blood pressure $(\geq 140 / 90 \mathrm{mmHg})$ at baseline, Y1, Y2 and Y3 was $68(56.7 \%), 51(43.2 \%), 48(42.1 \%)$ and $47(41.2 \%)$, respectively. The proportion of patients with increased blood pressure was significantly lower at $\mathrm{Y} 1(P=0.018)$, at $\mathrm{Y} 2$ $(P=0.030)$ and at Y3 $(P=0.017)$ vs baseline (McNemar's test).

Other measurements. Regarding the most recently recorded measurements (Table 4), triglyceride level was significantly lower at Y3 vs baseline (Wilcoxon test, $P=$ $0.004)$. The proportion of patients with increased total cholesterol $(\geq 5 \mathrm{mmol} / \mathrm{l})$ and with increased LDL-C ( $\geq 3 \mathrm{mmol} / \mathrm{l})$ and increased level of triglycerides $(\geq 1.7 \mathrm{mmol} / \mathrm{l})$ did not differ significantly in comparison with baseline data (McNemar's test, $P>0.05$ ), but the proportion of patients with decreased level of HDL-C $(<1.0 \mathrm{mmol} / \mathrm{l}$ for men and $<1.2 \mathrm{mmol} / \mathrm{l}$ for woman) significantly decreased at $\mathrm{Y} 1, \mathrm{Y} 2$ and Y3 vs baseline (McNemar's test $<0.001$ in all cases).

$\mathrm{LVEF}$ at baseline, at $\mathrm{Y} 1, \mathrm{Y} 2$ and $\mathrm{Y} 3$ was $57.1 \pm 8.7 \%$, $58.0 \pm 7.8 \%, 57.8 \pm 8.4 \%, 56.9 \pm 10.2 \%$, respectively. It did not differ at Y1-Y3 from baseline values (paired sample ttest, $P>0.05)$ and the proportion of patients with decreased LVEF ((\%) did not differ: $4(4.2 \%)$ at baseline, $1(1.9 \%)$ at Y1, $1(1.8 \%)$ at $\mathrm{Y} 2$ and $3(5.6 \%), P>0.05$, McNemar's test).

Current symptoms. Angina symptoms at baseline, Y1, Y2 and $\mathrm{Y} 3$ were present in $47.5 \%(\mathrm{n}=57), 39.0 \%(\mathrm{n}=46)$, $43.5 \%(n=50)$ and $37.7 \%(n=43)$ of patients, respectively. Significant improvement in angina symptoms was found at Y1 and Y3 vs baseline (Wilcoxon test, $P=0.001$ in both cases). In patients with angina, average consumption of ni- trates per month at baseline, $\mathrm{Y} 1, \mathrm{Y} 2$ and $\mathrm{Y} 3$ was $7.7 \pm 5.2$, $4.4 \pm 3.1,5.6 \pm 3.2$ and $5.1 \pm 3.4$, respectively. Consumption of nitrates decreased significantly at $\mathrm{Y} 1, \mathrm{Y} 2, \mathrm{Y} 3$ vs baseline (paired sample t-test, $P=0.001, P=0.015, P=$ 0.004, respectively).

The number of patients with heart failure at baseline and at Y1, Y2, Y3 was $69(57.5 \%), 69(68.5 \%), 73(63.5 \%)$ and 75 $(65.8 \%)$, respectively. Significant worsening in heart failure symptoms was found atY3 vs baseline data (McNemar's test, $P=0.022$ ).

Treatment. Treatment of patients with different classes of drugs is summarised in Table 5.

Preventive treatment. During the follow-up period, the number of patients receiving antithrombotic agents was invariably high (Table 5). The proportion of patients receiving antithrombotic agents and proportion of patients using statins and angiotensin-converting enzyme inhibitors (ACEI) or angiotensin-receptor blockers (ARB) did not differ at Y1-Y3 vs baseline data (McNemar's test, $P>0.05$ in all cases).

HR reducing agents. Regarding heart rate reducing agents, patients were using $\beta$ blockers and ivabradin (number of patients using these agents during the follow-up period are summarised in Table 5). No patient used digoxin or amiodaron as a single $\mathrm{HR}$ reducing agent without $\beta$ blocker or ivabradin. Non-dihidropiridin $\mathrm{Ca}$ antagonists were not used at all. Among $\beta$ blockers, metoprolol, bisoprolol, nebivolol and carvedilol were used. One patient at Y1 received betaxolol (10 mg/d). Most frequently, patients were receiving metoprolol and bisoprolol (Table 5). The proportion of patients using nebivolol significantly increased in $\mathrm{Y} 2$ and $\mathrm{Y} 3$ in comparison with baseline data (McNemar's test, $P=0.031$ in both cases). Average daily dose (ADD) of metoprolol at baseline, in Y1, Y2 and Y3 was the same: $\mathrm{Me}=50 \mathrm{mg} / \mathrm{d}, \mathrm{IQR}=50 \mathrm{mg} / \mathrm{d}$. ADD of another most frequently used $\beta$ blocker bisoprolol at baseline and in Y1-Y3 was the following: $\mathrm{Me}=5.0 \mathrm{mg} / \mathrm{d}, \mathrm{IQR}=0.0 \mathrm{mg} / \mathrm{d}$ except $\mathrm{Y} 1$, when $\mathrm{IQR}=2.5 \mathrm{mg} / \mathrm{d}$. ADD of $\beta$ blockers did not change over three-year period (Wilcoxon test, $P>0.050$ in all cases). Distribution of patients according to used dose of $\beta$ blocker is summarised in Table 6: no differences were found at $\mathrm{Y} 1, \mathrm{Y} 2$ and $\mathrm{Y} 3$ compared to baseline data (Wilcoxon test, $P>0.050$ in all cases).

The proportion of patients using ivabradin significantly increased at $\mathrm{Y} 1, \mathrm{Y} 2$ and $\mathrm{Y} 3$ in comparison with baseline data (McNemar's test, $P=0.016, P<0.001, P<0.001$, respectively). The median ADD of ivabradin at baseline and at $\mathrm{Y} 1-\mathrm{Y} 3$ was $5.0(\mathrm{IQR}=5.0) \mathrm{mg} / \mathrm{d}$ and $15.0(\mathrm{IQR}=5.0)$ $\mathrm{mg} / \mathrm{d}$, respectively. Doses of ivabradin at Y2, Y2 and Y3 significantly increased vs baseline values (Wilcoxon test, $P=0.002, P=0.002$ and $P=0.001$, respectively). The number of patients using ivabradin in combination with $\beta$ blocker was $3(2.5 \%)$ at baseline and $9(7.6 \%), 17(14.8 \%)$ $20(17.5 \%)$ at Y1, Y2 and Y3, respectively. The proportion of patients using this combination significantly increased at 
MOST RECENT MEASUREMENTS DURING THE FOLLOW-UP PERIOD

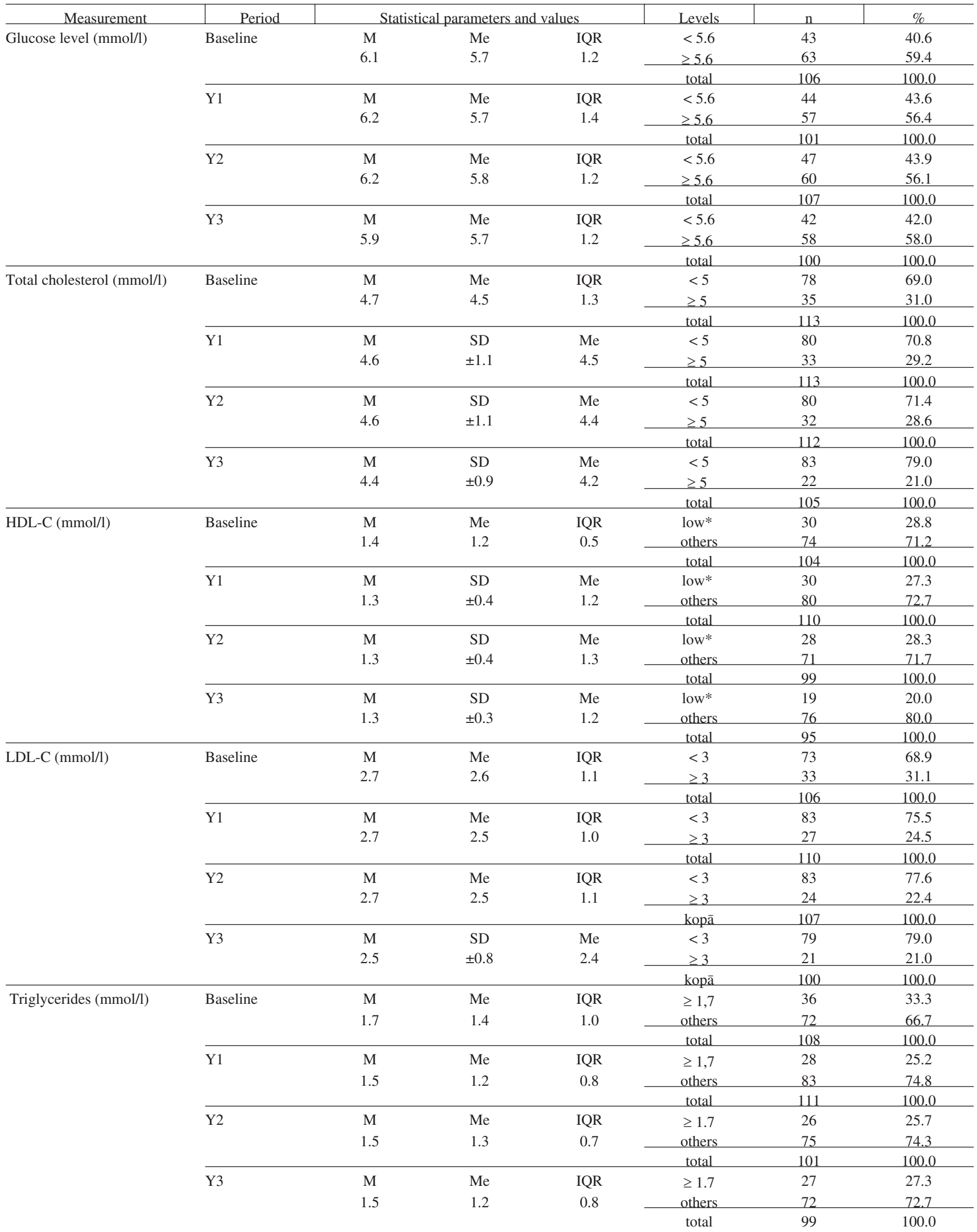

HDL-C, high density lipoprotein cholesterol; IQR, interquartile range; LDL-C, low density lipoprotein cholesterol. For other abbreviations see Table 1

$*<1.2 \mathrm{mmol} / \mathrm{l}$ for women and $<1.0 \mathrm{mmol} / \mathrm{l}$ for men 
USE OF THE MOST IMPORTANT CLASSES OF CARDIOVASCULAR DRUGS OVER THE THREE-YEAR PERIOD

\begin{tabular}{|c|c|c|c|c|c|c|c|c|}
\hline \multirow[t]{3}{*}{ Classes } & \multicolumn{8}{|c|}{ Number of patients receiving drugs } \\
\hline & \multicolumn{2}{|c|}{ baseline } & \multicolumn{2}{|c|}{$\mathrm{Y} 1$} & \multicolumn{2}{|c|}{$\mathrm{Y} 2$} & \multicolumn{2}{|c|}{$\mathrm{Y} 3$} \\
\hline & $\mathrm{n}$ & $\%$ & $\mathrm{n}$ & $\%$ & $\mathrm{n}$ & $\%$ & $\mathrm{n}$ & $\%$ \\
\hline $\begin{array}{l}\text { Antithrombotic } \\
\text { agents }\end{array}$ & 118 & 98.3 & 116 & 98.3 & 113 & 98.3 & 112 & 98.2 \\
\hline Statins & 113 & 94.2 & 113 & 95.8 & 111 & 96.5 & 111 & 97.4 \\
\hline AKEI/ARB & 103 & 85.5 & 103 & 87.3 & 103 & 89.6 & 103 & 90.4 \\
\hline B blockers (total) & 98 & 81.7 & 97 & 82.2 & 97 & 84.3 & 96 & 84.2 \\
\hline metoprolol & 47 & 39.2 & 46 & 39.0 & 45 & 39.1 & 45 & 39.5 \\
\hline bisoprolol & 37 & 30.1 & 33 & 28.0 & 32 & 27.8 & 33 & 28.9 \\
\hline nebivolol & 10 & 8.3 & 14 & 11.9 & 17 & 14.8 & 16 & 14.0 \\
\hline carvedilol & 4 & 3.3 & 3 & 2.5 & 3 & 2.6 & 2 & 1.8 \\
\hline betaksolol & 0 & 0.0 & 1 & 0.9 & 0 & 0.0 & 0 & 0.0 \\
\hline $\begin{array}{l}\mathrm{I}_{\mathrm{f}} \text { inhibitors } \\
\text { (ivabradin) }\end{array}$ & 15 & 12.5 & 22 & 18.6 & 29 & 25.2 & 32 & 28.1 \\
\hline $\mathrm{Ca}$ antagonists & 64 & 53.3 & 66 & 53.9 & 67 & 58.3 & 69 & 60.5 \\
\hline Nitrates & 28 & 23.3 & 30 & 25.4 & 31 & 27.0 & 30 & 26.3 \\
\hline $\begin{array}{l}\text { Other antianginal } \\
\text { agents }\end{array}$ & 15 & 12.5 & 17 & 14.4 & 20 & 17.4 & 21 & 18.4 \\
\hline Diuretics & 31 & 25.8 & 35 & 29.7 & 39 & 33.9 & 41 & 36.0 \\
\hline
\end{tabular}

ACEI, angiotensin-converting enzyme inhibitors; ARB, angiotensin-receptor blockers; n, number of patients; $Y$, year

Y1, Y2, Y3 comparing to baseline values (McNemar's test, $P=0.031, P<0.001, P<0.001$, respectively).

HR reducing agents in the group of patients with increased resting $\mathbf{H R} \geq \mathbf{7 0} \mathbf{b p m}$. Regarding patients with increased HR (documented at least in one visit), more than $90 \%$ of patients with $\mathrm{HR} \geq 70 \mathrm{bpm}, \geq 75 \mathrm{bpm}, \geq 80 \mathrm{bpm}$ and $\geq 85 \mathrm{bpm}$ were using $\beta$ blocker or ivabradin. However, HR reducing agents were not used at all in $6-8 \%$ of patients with increased HR: in $5(6.9 \%), 3(6.4 \%), 2(6.3 \%)$ and 2 $(5.0 \%)$ cases of patients with $\mathrm{HR} \geq 70 \mathrm{bpm}, \geq 75 \mathrm{bpm}, \geq 80$ bpm and $\geq 85 \mathrm{bpm}$, respectively (when HR was documented by pulse palpation) and in $4(6.8 \%), 3(6.7 \%), 2(9.7 \%)$ and $2(8.3 \%)$ cases of patients with $\mathrm{HR} \geq 70 \mathrm{bpm}, \geq 75 \mathrm{bpm}, \geq 80$
DISTRIBUTION OF PATIENTS USING $\beta$ BLOCKERS ACCORDING TO DOSE

\begin{tabular}{l|c|c|c|c|c|c|c|c}
\hline \multirow{2}{*}{$\begin{array}{c}\text { Dose of } \beta \\
\text { blocker }(\% \\
\text { from target } \\
\text { dose*) }\end{array}$} & \multicolumn{2}{|c|}{ Baseline } & \multicolumn{2}{c|}{ Y1 } & \multicolumn{2}{c|}{ Y2 } & \multicolumn{2}{c}{ Y3 } \\
\hline$<25$ & 5 & 5.1 & 6 & 6.2 & 8 & 8.2 & 7 & 7.3 \\
$25-49,9$ & 41 & 41.8 & 44 & 45.4 & 39 & 40.2 & 41 & 42.7 \\
$50-74,9$ & 45 & 45.9 & 41 & 42.3 & 45 & 46.4 & 43 & 44.8 \\
$75-99,9$ & 2 & 2.0 & 1 & 1.0 & 1 & 1.0 & 1 & 1.0 \\
100 & 5 & 5.1 & 5 & 5.2 & 4 & 4.1 & 3 & 3.1 \\
$>100$ & 0 & 0.0 & 0 & 0.0 & 0 & 0.0 & 1 & 1.0 \\
Total & 98 & 100.0 & 97 & 100.0 & 97 & 100.0 & 96 & 100.0
\end{tabular}

$\mathrm{n}$, number of patients; Y, year; * target dose for metoprolol - $200 \mathrm{mg} / \mathrm{d}$, for bisoprolol - $10 \mathrm{mg} / \mathrm{d}$, for nebivolol $-10 \mathrm{mg} / \mathrm{d}$, for carvedilol $-50 \mathrm{mg} / \mathrm{d}$, for betaksolol - $20 \mathrm{mg} / \mathrm{d}$

bpm and $\geq 85 \mathrm{bpm}$, respectively (when HR was documented by ECG).

The number of patients using ivabradin, $\beta$ blockers and ivabradin in combination with $\beta$ blockers according to HR are summarised in Table 7. Dividing patients in four categories according to HR (70-74 bpm, 75-79 bpm, 80-84 bpm and $\geq 85 \mathrm{bpm}$ ), parabolic regression analysis showed a significant parabolic relationship with a high determination coefficient between HR category and use of ivabradin, as well as frequency of $\beta$ blockers in combination with ivabradin: decrease or slight increase when HR was 75-79 bpm and 80-85 bpm in comparison with HR level 70-74 bpm and significant increase when HR was $\geq 85 \mathrm{bpm}$ (Table 8). Use of higher doses of $\beta$ blockers ( $\geq 50 \%$ from target dose) and frequency of $\beta$ blockers contraindications/side effects also changed parabolically: use of $\geq 50 \%$ of $\beta$ blockers target dose increased when HR was 70-74 bpm, 75-80 bpm and decreased when HR was $\geq 85 \mathrm{bpm}$; frequency of $\beta$ blockers contraindications/side effects increased when HR was higher (Table 9).

Other CV agents. All patients receiving $\mathrm{Ca}$ antagonists used dihydropyridine type $\mathrm{Ca}$ antagonists. At $\mathrm{Y} 2$ and $\mathrm{Y} 3$,

Table 7

USE OF BRADICARDIC AGENTS IN PATIENTS WITH INCREASED HEART RATE

\begin{tabular}{|c|c|c|c|c|c|c|c|c|c|c|c|c|}
\hline \multirow{3}{*}{$\begin{array}{l}\mathrm{HR}^{*} \\
(\mathrm{bpm})\end{array}$} & \multirow[t]{3}{*}{ Method } & \multirow[t]{3}{*}{$\mathrm{n}$} & \multirow{2}{*}{\multicolumn{2}{|c|}{$\begin{array}{l}\text { B blocker or } \\
\text { ivabradin** }\end{array}$}} & \multicolumn{4}{|c|}{ ß blocker** } & \multirow{2}{*}{\multicolumn{2}{|c|}{ Ivabradin** }} & \multirow{2}{*}{\multicolumn{2}{|c|}{$\begin{array}{l}\beta \text { blocker and } \\
\text { ivabradin** }\end{array}$}} \\
\hline & & & & & \multicolumn{2}{|c|}{ all doses } & \multicolumn{2}{|c|}{$\geq 50 \%$ from target dose } & & & & \\
\hline & & & $\mathrm{n}$ & $\%$ & $\mathrm{n}$ & $\%$ & $\mathrm{n}$ & $\%$ & $\mathrm{n}$ & $\%$ & $\mathrm{n}$ & $\%$ \\
\hline$\geq 70$ & palpation & 72 & 67 & 93.1 & 59 & 81.9 & 33 & 49.3 & 20 & 27.8 & 12 & 16.7 \\
\hline$\geq 75$ & palpation & 47 & 44 & 93.6 & 40 & 85.1 & 26 & 55.3 & 14 & 29.8 & 10 & 21.3 \\
\hline$\geq 80$ & palpation & 32 & 30 & 93.7 & 27 & 84.4 & 18 & 56.3 & 12 & 37.5 & 9 & 28.1 \\
\hline$\geq 85$ & palpation & 20 & 19 & 95.0 & 16 & 80.0 & 7 & 35.0 & 10 & 50.0 & 7 & 35.0 \\
\hline$\geq 70$ & ECG & 59 & 55 & 93.2 & 48 & 81.4 & 28 & 47.5 & 18 & 30.5 & 11 & 18.6 \\
\hline$\geq 75$ & ECG & 45 & 42 & 93.4 & 38 & 84.4 & 24 & 53.3 & 14 & 31.1 & 10 & 22.2 \\
\hline$\geq 80$ & ECG & 31 & 28 & 90.3 & 25 & 80.7 & 16 & 51.6 & 10 & 32.3 & 7 & 22.6 \\
\hline$\geq 85$ & ECG & 24 & 22 & 91.7 & 19 & 79.2 & 10 & 41.6 & 9 & 37.5 & 6 & 25.0 \\
\hline
\end{tabular}

bpm - beats per minute. For other abbreviations see Table 1; *documented at least in one visit; **used at least one year 
USE OF IVABRADIN AND ß BLOCKERS IN COMBINATION WITH IVABRADIN ACCORDING TO INCREASED HEART REATE CATEGORY

\begin{tabular}{|c|c|c|c|c|c|c|c|c|c|c|c|c|c|c|c|c|c|c|}
\hline \multirow{3}{*}{$\begin{array}{l}\text { HR* cate- } \\
\text { gory } \\
(\mathrm{bpm})\end{array}$} & \multicolumn{9}{|c|}{ Palpation } & \multicolumn{9}{|c|}{$\mathrm{ECG}$} \\
\hline & \multirow[t]{2}{*}{$\mathrm{n}$} & \multicolumn{4}{|c|}{ ivabradin** } & \multicolumn{4}{|c|}{$\begin{array}{l}\text { B blocker in combination with } \\
\text { ivabradin** }\end{array}$} & \multirow[t]{2}{*}{$\mathrm{n}$} & \multicolumn{4}{|c|}{ ivabradin*** } & \multicolumn{4}{|c|}{$\begin{array}{l}\text { ß blocker in combination with } \\
\text { ivabradin** }\end{array}$} \\
\hline & & $\mathrm{n}$ & $\%$ & $p$ & $\mathrm{R}^{2}$ & $\mathrm{n}$ & $\%$ & $\mathrm{p}$ & $\mathrm{R}^{2}$ & & $\mathrm{n}$ & $\%$ & $\mathrm{p}$ & $\mathrm{R}^{2}$ & $\mathrm{n}$ & $\%$ & $\mathrm{p}$ & $\mathrm{R}^{2}$ \\
\hline $70-74$ & 25 & 6 & 24.0 & \multirow{4}{*}{$\hat{\varrho}$} & \multirow{4}{*}{$\begin{array}{l}\circ \\
\stackrel{0}{0} \\
+\end{array}$} & 2 & 8.0 & \multirow{4}{*}{$\hat{\stackrel{\rho}{o}}$} & \multirow{4}{*}{$\dot{8}$} & 14 & 4 & 28.6 & \multirow{4}{*}{$\begin{array}{l}\hat{\imath} \\
\dot{\theta}\end{array}$} & \multirow{4}{*}{ : } & 1 & 7.1 & \multirow{4}{*}{$\stackrel{\dot{\theta}}{\operatorname{vi}}$} & \multirow{4}{*}{ 官 } \\
\hline $75-79$ & 15 & 2 & 13.3 & & & 1 & 6.7 & & & 14 & 4 & 28.6 & & & 3 & 21.4 & & \\
\hline $80-85$ & 12 & 2 & 16.7 & & & 2 & 16.7 & & & 7 & 1 & 14.3 & & & 1 & 14.3 & & \\
\hline$\geq 85$ & 20 & 10 & 50.0 & & & 7 & 35.0 & & & 24 & 9 & 37.5 & & & 6 & 25.0 & & \\
\hline
\end{tabular}

bpm, beats per minute; $\mathrm{p}$, significance coefficient for parabolic regression; $\mathrm{R}^{2}$, determination coefficient. For other abbreviations see Table $1 ; *$ documented at least in one visit; **used at least one year

Table 9

USE OF HIGHER DOSES OF ß BLOCKERS AND FREQUENCY OF ß BLOCKERS INTOLERANCE ACCORDING TO INCREASED HEART REATE CATEGORY

\begin{tabular}{|c|c|c|c|c|c|c|c|c|c|c|c|c|c|c|c|c|c|c|}
\hline \multirow{3}{*}{$\begin{array}{l}\text { HR* cate- } \\
\text { gory } \\
\text { (bpm) }\end{array}$} & \multicolumn{9}{|c|}{ Palpation } & \multicolumn{9}{|c|}{ ECG } \\
\hline & \multirow[t]{2}{*}{$\mathrm{n}$} & \multicolumn{4}{|c|}{$\geq 50 \%$ of $\beta$ blocker dose $* *$} & \multicolumn{4}{|c|}{$\begin{array}{l}\beta \text { blockers contraindica- } \\
\text { tions/side effects** }\end{array}$} & \multirow[t]{2}{*}{$\mathrm{n}$} & \multicolumn{4}{|c|}{$\geq 50 \%$ of $\beta$ blocker dose $* *$} & \multicolumn{4}{|c|}{$\begin{array}{l}\beta \text { blockers contraindica- } \\
\text { tions/side effects } * *\end{array}$} \\
\hline & & $\mathrm{n}$ & $\%$ & $\mathrm{p}$ & $\mathrm{R}^{2}$ & $\mathrm{n}$ & $\%$ & $\mathrm{p}$ & $\mathrm{R}^{2}$ & & $\mathrm{n}$ & $\%$ & $\mathrm{p}$ & $\mathrm{R}^{2}$ & $\mathrm{n}$ & $\%$ & $\mathrm{p}$ & $\mathrm{R}^{2}$ \\
\hline $70-74$ & 25 & 7 & 28.0 & \multirow{4}{*}{$\hat{\stackrel{\theta}{\theta}}$} & \multirow{4}{*}{$\stackrel{\circ}{\grave{2}}$} & 8 & 32.0 & \multirow{4}{*}{$\stackrel{\hat{\rho}}{\hat{g}}$} & \multirow{4}{*}{$\begin{array}{l}0 \\
\infty \\
\dot{\infty}\end{array}$} & 14 & 4 & 28.6 & \multirow{4}{*}{$\stackrel{\wedge}{\dot{\theta}}$} & \multirow{4}{*}{$\begin{array}{l}0 \\
\infty \\
N \\
\sigma\end{array}$} & 7 & 50.0 & \multirow{4}{*}{$\stackrel{\ominus}{\dot{8}}$} & \multirow{4}{*}{$\begin{array}{l}\stackrel{0}{+} \\
\stackrel{+}{N} \\
\pm\end{array}$} \\
\hline $75-79$ & 15 & 8 & 53.3 & & & 4 & 26.7 & & & 14 & 8 & 57.1 & & & 2 & 14.3 & & \\
\hline $80-85$ & 12 & 11 & 91.7 & & & 2 & 16.7 & & & 7 & 6 & 85.7 & & & 3 & 42.9 & & \\
\hline$\geq 85$ & 20 & 7 & 35.0 & & & 10 & 50.0 & & & 24 & 10 & 41.7 & & & 4 & 41.7 & & \\
\hline
\end{tabular}

For abbreviations see Table $8 ; *$ documented at least in one visit; **at least in one year

the proportion of patients using $\mathrm{Ca}$ antagonists significantly increased in comparison with baseline data (McNemar's test, $P=0.039$ and $P=0.012$, respectively). The proportion of patients using nitrates did not change vs baseline data (McNemar's test, $P>0.050$ ). The number of patients using other antianginal agents (trimetazidin in all cases, except one patient at Y2 and Y3 using ranolazin) was: $15(12.5 \%)$ at baseline $17(14.4 \%)$ at Y1, $20(17.4 \%)$ and $21(18.4 \%)$ at $\mathrm{Y} 3$ and it increased at Y3 vs baseline (McNemar's test, $P=$ $0.031)$. The proportion of patients using diuretics increased at Y1, Y2 and Y3 vs baseline (McNemar's test, $P=0.031$, $P=0.004$ and $P<0.001$, respectively).

\section{DISCUSSION}

Observed clinical outcomes in our study are typical for CAD patients, with domination of non-fatal coronary events (coronary angiography, unstable angina, PCI). The documented fatal events were connected with progression or complications of $\mathrm{CV}$ disease, as in the majority of deceased patients, cause of death was CV. Our data did not show the well known relationship between increased $\mathrm{HR}$ and $\mathrm{CV}$ events (including mortality) (Diaz et al., 2005; Fox et al., 2008a). Although HR in deceased patients was higher than in patients who survived, the difference does not reach statistical significance. This is probably connected with a low sample size of observed patients and too short follow-up period.

In our study, the proportion of patients using preventive treatment (Fox, 2006) was high, indicating a favourable trend to follow guidelines and consider $\mathrm{CV}$ prevention by treating $\mathrm{CAD}$ patients. However, the high mortality rate from CV diseases in Latvia (Anonīms, 2011) indicates a need to use all possibilities by practitioners to control $\mathrm{CV}$ RFs when treating CAD patients.

Data from analysed sample indicates a good tendency for better control of several important RFs over the three-year period: mean number of smoked cigarettes per day in smokers decreased, systolic blood pressure as well as number and proportion of patients with increased blood pressure decreased significantly. Also, control of dyslipidemia improved, as the level of triglycerides decreased, and proportion of patients with normal HDL-C increased. This seems encouraging and shows a connection between regular control of CAD patients by practitioners and progress in management of RFs, even during the relatively short period of time. However, this is not the case with HR. In our sample the percentage of CAD patients with increased HR $(\geq 70$ bpm) was lower than in the Euro Heart Survey (EHS) and REALITY Latvia (Daly et al., 2008; Balode et al., 2010), but the proportion of patients with increased HR $(\geq 70 \mathrm{bpm})$ did not change over the three-year period. EHS analysed information from 156 cardiology clinics in 34 countries with 3031 patient included, on the basis of a new clinical diagnosis of stable angina by a cardiologist (Daly et al., 2006). In EHS, the proportion of patients with increased HR $(\geq 70$ bpm) was 53\% (Daly et al., 2008). REALITY Latvia results are particularly interesting, as this study reflects the situation in Latvia with stable angina management four years before the start of our study. That study analysed 300 stable 
angina outpatients treated by cardiologists and highlighted increased HR and its management (Balode et al., 2010). The proportion of patients with increased HR $\geq 70 \mathrm{bpm}$ in REALITY Latvia was $43 \%$. In our study the proportion of patients with increased HR was lower (36\% by pulse palpation and $34 \%$ by ECG at the beginning of study). This suggests that HR management has improved, as REALITY Latvia was performed seven years ago. However, the patients in REALITY Latvia and in our study are not the same. Examination of HR control in our study during a three-year follow-up period of the same population suggests lack of improvement in HR. The proportion of patients with increased HR was high (around one-third) and stable over the three-year period, indicating a need for better control of this RF. HR is one of the most frequently assessed clinical parameters, which can be easily followed even by patients, and should be better controlled, especially taking into account the strong association of increased HR with CV events (Fox et al., 2008a) in CAD patients.

The current study does not indicate movement of patients from the group with increased HR to the group with normal HR or vice versa, over the follow-up period. It does not answer the question if patients did not respond to treatment with HR reducing agents. That type of analysis would be very useful in further studies.

Our data indicate unused potential for better control of HR. The most commonly used agents with HR reducing effect are $\beta$ blockers. The proportion of patients using $\beta$ blockers was high (more than $80 \%$ ), but the used doses were far from $\beta$ blocker target doses. Long-term compliance and underdosing of $\beta$ blockers is typical, as in real life patients are using significantly less dosages than those used in clinical trials (Gislason, 2006). Around 50\% of patients on $\beta$ blockers in our study were using $2 \%$ of the target dose and our data did not show any change in doses of $\beta$ blockers used over the three-year period. Use of nebivolol, a $\beta$ blocker with relatively weak HR reducing effect, increased during the follow-up period. Also, in 6-8\% of cases, despite increased HR, patients did not use any HR reducing agent. In our study, patients were mainly treated by cardiologists. In real life, stable CAD patients are more frequently treated by general practitioners. As understanding of increased HR as an independent CV RF and important target for treatment can be significantly lower among general practitioners, in comparison with cardiologists, HR control in patients treated by general practitioners is likely even weaker.

However, there are some positive tendencies in management of $\mathrm{HR}$ - practitioners are starting to use ivabradin more frequently, as well as more commonly combining $\beta$ blockers with ivabradin. Ivabradin is good HR lowering agent without influence on other cardiac functions and provides antianginal and antiishemic efficacy in case of angina (Anonymous, 2013b). There is also evidence about ability of ivabradin to reduce risk of events (Fox et al., 2008b; Fox et al., 2009; Swedberg et al., 2010). Our data show that use of ivabradin is more frequent when HR is significantly higher than $70 \mathrm{bpm}-$ at the level $\geq 85 \mathrm{bpm}$. In those patients, higher doses of $\beta$ blockers ( $\geq 50$ from target dose) were less frequently used, probably due to side effects, as incidence of b blocker intolerance was higher in this group. Insufficient reduction of $\mathrm{HR}$ is indication for combination of $\beta$ blocker with ivabradin. However, our data suggest that ivabradin is added to treatment not because of HR, but because of intolerance of $\beta$ blockers. Newest European as well Latvian heart failure guidelines recommend adding ivabradin when HR is $\geq 70 \mathrm{bpm}$ (McMurray et al., 2012). Use of higher doses of $\beta$ blockers and more frequent combination with ivabradin in patients with $\geq 70 \mathrm{bpm}$ could be potentially beneficial for better control of HR in CAD patients.

Limitations for interpretation of the results should be acknowledged, as the number of patients involved was relatively small and the follow-up period was rather short. Selection bias may also have taken place. For better understanding of how management of increased HR and other RFs in stable CAD patients is changing, studies with a bigger number of patients and a longer follow-up period are needed. The results of the study indicate improvement over the three-year period in the management of several important RFs, like smoking, increased blood pressure as well dyslipidemia, in the analysed sample of treated outpatients with established CAD.

However, prevalence of patients with increased HR $(\geq 70$ bpm) remained high (around one-third) and stable, indicating a need for better control.

Use of higher doses of $\beta$ blockers and more frequent combination of $\beta$ blockers with ivabradin in patients with $\mathrm{HR} \geq 70$ bpm could be an unused potential for better control of increased HR and an additional step towards reduction of coronary events and improvement of symptoms in CAD patients.

\section{ACKNOWLEDGMENTS}

This survey was supported by Servier Latvia. Study Coordinator Andrejs Erglis, investigators Gustavs Latkovskis, Iveta Mintāle and authors are grateful to all investigators: Santa Ābele, Anita Baika, Veronika Ečina, Silvija Hansone, Inga Jasinkevica, Inara Laizāne, Irina Mihailova, Ausma Kondratoviča, Natalja Pontāga, Nadežda Rožkova.

\section{REFERENCES}

Alberti, K. G., Zimmet, P., Shaw, J. (2005). The metabolic syndrome - a new worldwide definition. Lancet, 366 (9491), 1059-1062.

Anonīms (2011). Latvijas veselības statistikas gadagrāmata par 2010. gadu [Annual Book of Latvian Health Statistics about 2010]. Rīga: VSMTVA (Veselības statistikas un medicīnas tehnolog̣iju valsts ağentūra) (in Latvian).

Anonīms (2013a). Lokren zāḷu paraksts.

http://www.zva.gov.lv/zalu-registrs/?iss=1\&lang=lv\&q=Betax $\& O N=\& S$ $\mathrm{N}=\& \mathrm{NAC}=$ on $\& \mathrm{RN}=\& \mathrm{ESC}=\mathrm{on} \& \mathrm{AK}=\& \mathrm{SAT}=\mathrm{on} \& \mathrm{RA}=\& \mathrm{DEC}=\mathrm{on} \& \mathrm{LB}=$ $\& P I M=$ on (last accessed 20.07.2013)

Anonymous (2013b). Procoralan SPC (Summary of Product Characteristics).

http://www.ema.europa.eu/docs/lv_LV/document_library/EPAR_-_Product_Information/human/000597/WC500043590.pdf (last accessed 20.07.2013) 
Balode, I., Jēgere, S., Mintāle, I., Narbute, I., Zakke, I., Latkovskis, G., Ērglis, A. (2010). Current state of angina treatment in the outpatient population and heart rate monitoring survey in Latvia (REALITY Latvia). Proc. Latvian Acad. Sci. Sect. B, 64 (5/6), 194-201.

Balode, I., Jēgere, S., Mintāle, I., Narbute, I., I., Latkovskis, G., Ērglis, A. (2011) Heart rate and other risk factors in outpatients with stable coronary artery disease in Latvia. Proc. Latvian Acad. Sci. Sect. B, 65 (3/4), 94-101.

Bohm, M., Swedberg, K., Komajda, M., Borer, J., Ford, I., Dubost-Brama, A., Lerebous, G., Tavazzi, L., on behalf of the SHIFT investigators (2010). Heart rate as a risk factor in chronic heart failure (SHIFT): The association between heart rate and outcomes in a randomised placebo-controlled trial. Lancet, 376 (9744), 886-94.

Daly, C. A., De Stavola, B., Lopez-Sendon, J. L., Tavazzi, L, Boersma, E., Clemens, F., Danchin, N., Delahaye, F., Gitt, A., Julian, D., Mulcahy, D., Ruzyllo, W., Thygesen, K., Verheugt, F., Fox K. M. (2006) Predicting prognosis in stable angina - results from the Euro Heart Survey of stable angina: Prospective observational study. BMJ, 332, 262-267.

Daly, C., Tavazzi, L., Fox, K., Euro Heart Survey of Angina Investigators (2008). Inadequate control of heart rate in patients with stable angina: Results from the European Heart Survey. Eur. Heart J., 29 (Abstract Supplement), 204.

Diaz, A., Bourassa, M. G., Guertin, M. C., Tardif, J. C. (2005). Long term prognostic value of resting heart rate in patients with suspected or proven coronary artery disease. Eur. Heart J., 26 (10), 967-974.

Ērglis, A., Kalvelis, A., Lejnieks, A., Dzērve, V., Latkovskis, G., Mintāle, I., Zakke, I., Rasa, I. (2007). Kardiovaskulāro slimību (KVS) profilakses vadlinijas [Guidelines on Cardiovascular Disease Prevention]. Rīga: Latvijas Kardiologu biedrība (in Latvian)

Ērglis, A., Jēgere, S., Kalējs, O., Kalvelis, A., Kamzola, G., Lācis, J., Mača, A., Mintāle, I., Narbute, I., Stradin̄š, P., Zakke, I. (2012). Hroniskas sirds mazspējas klīniskās vadlīnijas [Guidelines on Heart Failure Management]. Rīga: Latvijas Kardiologu biedrība (in Latvian).

Fox, K., Garcia, M. A. A., Ardissino, D., Buszman, P., Camici, P. G., Crea, F., Daly, C., Backer, G., Hjemdahl, P., Lopes-Sendon, J., Marco, J., Morais, J., Pepper, J., Sechtem, U., Simoons, M., Thygesen, K. (2006). Guidelines on the management of stable angina pectoris. The Task Force on the Managment of Stable Angina Pectoris of the European Society of Cardiology. Eur. Heart J., 27, 341-1381.

Fox, K., Ford, I., Steg, P. G., Tendera, M., Robertson, M., Ferrari, R., BEAUTIFUL investigators (2008a). Heart rate as a prognostic risk factor in patients with coronary artery disease and left-ventricular systolic dysfunction (BEAUTIFUL): A subgroup analysis of a randomised controlled trial. Lancet, 372 (9641), 817-821.

Fox, K., Ford, I., Steg, P. G., Tendera, M., Ferrari, R., BEAUTIFUL investigators (2008b) Ivabradine for patients with stable coronary artery disease and left-ventricular systolic dysfunction (BEAUTIFUL): A randomised, double-blind, placebo-controlled trial. Lancet, 372, 807-816.

Fox, K., Ford, I., Steg, P. G., Tendera, M., Robertson, M., Ferrari, R., BEAUTIFUL investigators (2009). Relationship between ivabradine treatment and cardiovascular outcomes in patients with stable coronary artery disease and left ventricular systolic function with limiting angina: A subgroup analysis of the randomized, controlled BEAUTIFUL trial. Eur. Heart J., 30, 2337-2345.

Gislason, G. H., Rasmussen, J. N., Abildstrom, S. Z., Gadsboll, N., Buch, P., Friberg, J., Rasmussen, S., Kober, L., Stender, S., Madsen, M., and Torp-Pederden, C. (2006). Long term compliance with beta-blockers, angiotensin-converting inhiitors, and statins after acute myocardial infarction. Eur. Heart Journal, 27, 1153-1158.

Graham, I., Atar, D., Borch-Johnsen, K., Boysen, G., Burell, G., Cifkova, R., Dallongeville, J., De Backer, G., Ebrahim, S., Gjelsvik, B., HerrmannLingen, C., Hoes, A., Humphries, S., Knapton, M., Perk, J., Priori, S. G., Pyorala, K., Reiner, Z., Ruilope, L., Sans-Menendez, S., Reimer, V. S. O., Weissberg, P., Wood, D., Yarnell, Y., Zamorano, J. L. (2007). European guidelines on cardiovascular disease prevention in clinical practice: Executive summary. Eur. Heart J., 28, 2375-2414.

Leal, J., Luengo-Fernández, R., Gray, A., Petersen, S., Rayner, M. (2006). Economic burden of cardiovascular diseases in the enlarged European Union. Eur. Heart J., 27 (13), 1610-1619.

Lopez-Sendon, J., Swedberg, K., McMurray J., Tamargo, J., Maggioni, A. P., Dargie, H.,Tendera, M., Waagstein, F., Kjekshus, J., Lechat, P., Torp-Pedersen, C. (2004) Expert consensus document on B-adrenergic receptor blockers. The Task Force on Beta-Blockers of the European Society of Cardiology. Eur. Heart J., 25, 1341-1362.

Mathers, C. D., Loncar, D. (2006). Projections of global mortality and burden of disease from 2002 to 2030. PLoS Med., Nov, 3, e442.

McMurray, J. J. V., Adamopoulos, S., Anker, S. D., Auricchio, A., Bohm, M., Dickstein, K., Falk, V., Filippatos, G., Fonseca, C., Gomez-Sanchez, M. A., Jaarsm, T., Køber, L., Lip, G. Y. H., Maggioni, A. P., Parkhomenko, A., Pieske, B. M., Popescu, B. A., Rønnevik, P. K., Rutten, F. H., Schwitter, J., Seferovic, P., Stepinska, J., Trindade, P.T., Voors, A. A., Zannad, F., Zeiher, A. (2012). ESC Guidelines for the diagnosis and treatment of acute and chronic heart failure 2012. The Task Force for the Diagnosis and Treatment of Acute and Chronic Heart Failure 2012 of the European Society of Cardiology. Developed in collaboration with the Heart Failure Association (HFA) of the ESC. Eur. Heart J., 33, 1787-1847.

Perk, J., De Backer, G., Gohlke, H., Graham, I., Reiner, Z., Verschuren, W. M. M., Christian Albus, C., Benlian, P., Boysen, G., Cifkova, R., Deaton, C., Ebrahim, S., Fisher, M., Germano, G., Hobbs, R., Hoes, A., Karadeniz, S., Mezzani, A., Prescott, E., Ryden, L., Scherer, M., Syvanne, M., Scholte Op Reimer, W. J. M., Vrints, C., Wood, D., Zamorano, J. S. Zannad, F. (2012). European Guidelines on cardiovascular disease prevention in clinical practice (version 2012). Eur. Heart J., 33, 1635-1701.

Tunstall-Pedoe, H., Kuulasmaa, K., Mähönen, M., Tolonen, H., Ruokokoski, E., Amouyel, P., for the WHO MONICA (monitoring trends and determinants in cardiovascular disease) Project (1999). Contribution of trends in survival and coronary-event rates to changes in coronary heart disease mortality: 10-year results from 37 WHO MONICA Project populations. Lancet, 353, 1547-1557.

Swedberg, K., Komajda, M., Bohm, M., Borer, J., Ford, I., Dubost-Brama, A., Lerebous, G., Tavazzi, L., on behalf of the SHIFT investigators (2010). Ivabradine and outcomes in chronic heart failure (SHIFT): A randomised placebo-controlled study. Lancet, 376, 875-885.

Received 9 September 2013

\section{SIRDSDARBĪBAS FREKVENCES UN CITU RISKA FAKTORU KONTROLE TRĪS GADU PERIODĀ LATVIJĀ AMBULATORI ĀRSTĒTIEM PACIENTIEM AR STABILU KORONĀRO SIRDS SLIMĪBU}

Pētījuma mērkis bija novērtēt palielinātas sirdsdarbības frekvences (SF) un citu riska faktoru (RF) kontroli trīs gadu ilgā novērošanas periodā ambulatori ārstētiem pacientiem ar stabilu koronāro sirds slimību (KSS). Pacienti $(n=120)$ tika iztaujāti un izmeklēti kopumā četras reizes — sākotnēji un ik gadu trīs gadus pēc kārtas. Palielināta sirdsdarbības frekvence $(\geq 70 \mathrm{x} / \mathrm{min})$, nosakot to ar palpācijas metodi, sākotnēji un trijos novērošanas gados attiecīgi bija 35,8\% 35,6\%, 29,85 un 35,1\%; nosakot ar elektrokardiogrāfijas metodi, 33,6\%, 36,8\%, $26,75 \%$ un $33,7 \%$. Šo pacientu îpatsvars trīs gadu novērošanas periodā statistiski ticami nemainījās. Sistoliskais asinsspiediens pirmajā un trešajā novērošanas gadā bija ticami zemāks nekā sākotnēji (attiecīgi, $P=0,005$ un $P=0,003$ ). Pacientu ar palielinātu asinsspiedienu $(\geq 140 / 90 \mathrm{mmHg})$ īpatsvars statistiski ticami samazinājās pirmajā $(43,2 \%)$, otrajā $(42,1 \%)$ un trešajā $(41,2 \%)$ novērošanas gadā salīdzinājumā ar sākotnējiem datiem $(56,7 \%)$ (attiecīgi, $P=0,018, P=0,030$ un $P=0,017)$. Tāpat pirmajā, otrajā un trešajā novērošanas gadā bija būtiski mazāks to pacientu īpatsvars, kuriem bija pazemināts augsta blīvuma lipoproteīnu holesterīna līmenis $(<1,2 \mathrm{mmol} / 1$ sievietēm un $<1,0 \mathrm{mmol} / \mathrm{l}$ vīriešiem $)(27,3 \%, 28,3 \%, 20,0 \%$ vs $28,8 \%, P<0,001$ visos gadījumos). Fakts, ka, neraugoties uz ārstēšanu, nozīmīgam analizēto KSS pacientu skaitam (apmēram trešajai daḷai) saglabājas palielināta SF un šādu pacientu proporcija laika gaitā būtiski nemainās, norāda, uz nepieciešamību labāk kontrolēt šo nozīmīgo RF. 